\title{
Systematization of Methodical Approaches to the Analysis of Economic Entity Sustainable Development
}

\author{
O. Likhtarova ${ }^{1, *}$ \\ *Corresponding author: lihtarova.olga@yandex.ru. \\ ${ }^{1}$ Samara State Economic University, Samara, Russia
}

\begin{abstract}
The main approaches to the calculation and classification of indicators used for assessment of the economic entity sustainable development are considered in the study. Methodological advantages and shortcomings of approaches to the development of the system of indicators of an organization sustainable development within stakeholder approach are analyzed. The results of comparative analysis of the main international and Russian methodological approaches to the formation of the system of indicators for assessment of economic entity sustainable development are presented. The conclusion is drawn that in terms of stakeholder approach methodological approaches to the formation of integrated assessment of the organization sustainable development level on the basis of the formation of indexes and rating models are of great scientific and practical interest.
\end{abstract}

Keywords: stakeholder, sustainable development, indexes and rating of sustainable development, indexes of development.

\section{Introduction}

Today the methodology of the assessment of economic entities development on the basis of stakeholders' requirements is widely discussed in the researches of Russian and foreign scientists. Practical interest in the formation of a system of indicators of an economic entity sustainable development on the basis of stakeholders' requirements is caused by the fact that the balance of interests of an economic subject and interested parties are the leading factor of sustainable development of a social-economic system in general in the conditions of the developed market infrastructure [1].

\section{Problem Statement}

The identification of features and criteria of the analysis, the assessment and monitoring of activity of an economic entity within the concept of sustainable development demands a further specification in the form of the complete system of indicators for tasks of management $[2,3,4]$. The task of the analysis of the main approaches to the evaluating and monitoring of activity of an economic entity was set in the research.

Considering contents and features of evaluating an economic entity development on the basis of stakeholder approach, it should be noted that the important aspect of such an assessment is the dynamic nature of the parties' interest. In general, the degree of the parties' interest and also their concern about the activity of the organization is capable to change. So, at an initial stage only some individuals and legal entities who are stakeholders can express the concern about the activity of the organization [5]. Some time later more stakeholders including those of primary groups can show their concern. In process of other interested parties' more awareness (including through information publicity of problems and contradictions in mass media) all primary groups of stakeholders can show concern about activity of the organization [6].

\section{Research Questions}

The carried-out analysis of various scientific points of view on the quantity of stages in development of social interactions submitted R.W. Ackerman's works [7], R.A. Buchholz [8], S.C. Zyglidopoulos [9], R. Van Tulder and A. Van Der Zwald [10], S. Zadek [11], allowed to draw the following conclusions. The stakeholders' concern, the level of their interaction among themselves and the extent of intervention in the activity of the organization begins in the insignificance period (when only some individuals and legal entities are interested), develops through the period of high awareness of stakeholders (it is noted by the growth of attention from mass media, the population, public authorities and local self-government), to the stage of the institutionalization of new management decisions and the practice (when there are formal and informal changes in the management practice not only of the economic entity, but also in the institutional environment in general). 


\section{Purpose of the Study}

The purpose of study is the development of the system of indicators for carrying out the analysis, the assessment and monitoring of an economic entity activity. For the achievement of a research goal the following complex of research problems was created:

- definition of the most optimum approaches to the analysis and the assessment of economic entity sustainable development;

- synthesis of the main scientific approaches to calculate and subsequently to group the indicators used for the analysis and assessment of economic entity sustainable development;

- systematization of methodological advantages and shortcomings of the main approaches to assessment of the organization sustainable development within stakeholder approach.

\section{Research Methods}

The research is based on the system approach assuming complex studying and structural and logical streamlining of a cluster as a complex economic system; methods of structural and comparative analysis were also applied. The solution of the given questions demanded the application of the following general theoretical research methods: abstraction and specification, analysis and synthesis, induction and deduction, comparison and opposition.

\section{Findings}

At the same time, there were several points of view on the methods of calculation and the subsequent grouping of the indicators used for assessment of an economic entity development in the economic literature. Yu.A. Sedykh developed a model of assessment of the industrial enterprises development which can be also applied within the stakeholder approach. The peculiarity of such a model is the possibility of evaluating the rationality of the choice of one of the integrated directions of an organization capital use (financial, production, human, etc.). This model of assessment consists of four key blocks of indicators which include:

- analysis of the potential of branch commodity markets, works and services;

- identification of the organization development barriers within the considered branch market;

- definition of key indicators of an economic entity development;

- assessment of risk level of conducting economic activity [12].

Russian economist E.V. Korobeynikova suggest carrying out the system assessment of an economic entity development on the basis of cooperation communications and interaction with products consumers. The ranging of development indicators considering their deviations from values, optimum for this industry is carried out within this approach to the assessment of the organization. Optimum values are defined on the basis of expert assessment. E.V. Korobeynikova offer the following groups of development indicators of an economic entity: indicators of economic development; indicators of social development; integrated indicators of development [13].

Methodological advantages and shortcomings of the following approaches to development of the system of indicators of the organization sustainable development within stakeholder approach were analysed in the research:

1. Project approach to the evaluating and monitoring of an economic entity activity within the realization of sustainable development strategy. Methodological feature of project approach is more expressed binding of indicators to specific goals and tasks of the organization and also indicators of their achievement [14].

2. The matrix approach to the formation of a system of indicators of effectiveness and efficiency of an economic entity activity within stakeholder approach which includes definition of strategic objectives achievement extent and problems of sustainable development of the organization on the basis of meeting requirements of interested parties [15].

3. Rating approach to the assessment and monitoring of an economic entity activity for the purpose of formation of an integrated indicator of an economic entity sustainable development. The most significant rating assessments for practice of management are the following: Bloomberg ESG Index, Dow Jones Sustainability Index, etc.

4. The approach on the basis of formation of sustainable development standards consisting in preparation the standardized form of the reporting assuming the disclosure of information on the indicators the organization stakeholders are interested in. It is possible to give Global Reporting Iniciative (GRI) as an example of this approach implementation to assess and monitor the activity of an economic entity.

Respectively, the application of each of the listed above approaches to the assessment of stability and balance of economic entity activity has a certain area and application conditions and has to be agreed with the purposes of the organization strategic development. Therefore, the analysis and critical judgment of the organization purposes and problems of sustainable development allow to choose the most optimum approach and on its basis to create analytical tools.

On the basis of the analysis of the main international and Russian methodological approaches to formation of a system of indicators for assessment of economic entities sustainable development table 1 was made which contains the comparative analysis of methodological advantages and shortcomings of techniques of disclosure of information on the organization sustainable development. 
Table 1. Comparative analysis of methodological advantages and shortcomings of techniques of disclosure of information on the organization sustainable development.

\begin{tabular}{|c|c|c|}
\hline $\begin{array}{l}\text { Technique of } \\
\text { sustainable } \\
\text { development } \\
\text { assessment }\end{array}$ & Methodological advantages & Methodological shortcomings \\
\hline $\begin{array}{c}\text { Technique «Bloomberg } \\
\text { ESG Index» }\end{array}$ & $\begin{array}{l}\text { - orientation to the information disclosure which } \\
\text { stakeholders are interested to; } \\
\text { - it is carried out in a section of different types of } \\
\text { economic activity for the purpose of carrying out } \\
\text { comparative analysis; } \\
\text { - ability to integrate into analytical model of key } \\
\text { performance indicators of the organization. }\end{array}$ & $\begin{array}{l}\text { - covers the largest corporations } \\
\text { presented at the global market; } \\
\text { - does not correlate with the system of } \\
\text { the Russian accounting and static } \\
\text { account, regulations on accounting; } \\
\text { - has high specificity of branch } \\
\text { indicators. }\end{array}$ \\
\hline $\begin{array}{l}\text { Techniques «Dow Jones } \\
\text { Sustainability Index», } \\
\text { «Global } 100 \text { Index» }\end{array}$ & $\begin{array}{l}\text { - combination of traditional indicators of the } \\
\text { analysis with non-material factors of } \\
\text { competitiveness; } \\
\text { - it is carried out in a section of different types of } \\
\text { economic activity for the purpose of carrying out } \\
\text { comparative analysis. }\end{array}$ & $\begin{array}{l}\text { - it is carried out on the basis of } \\
\text { voluntary questioning of the } \\
\text { organizations; } \\
\text { - covers the largest corporations } \\
\text { presented at the global market; } \\
\text { - does not correlate with the system of } \\
\text { the Russian accounting and static } \\
\text { account, regulations on accounting. }\end{array}$ \\
\hline $\begin{array}{c}\text { Technique «Global } \\
\text { Reporting Initiative» } \\
\text { (GRI) }\end{array}$ & $\begin{array}{l}\text { - broad coverage of indicators of the organization } \\
\text { corporate responsibility; } \\
\text { - it is focused on the public reporting before } \\
\text { stakeholders; } \\
\text { - it is constructed on standardization of data with } \\
\text { the purpose of comparative analysis; } \\
\text { - contains mechanisms of assessment of the } \\
\text { organization strategic development and support } \\
\text { of management decisions adoption. }\end{array}$ & $\begin{array}{l}\text { it is suitable for sustainable } \\
\text { development assessment of the large } \\
\text { industrial enterprises; } \\
\text { - does not correlate with the system of } \\
\text { the Russian accounting and static } \\
\text { account, regulations on accounting; } \\
\text { - demands high level of training of } \\
\text { economists. engaged in the reporting, } \\
\text { rather labor-consuming. }\end{array}$ \\
\hline $\begin{array}{l}\text { Technique of the } \\
\text { Russian Union of } \\
\text { Industrialists and } \\
\text { Entrepreneurs (RUIE) }\end{array}$ & $\begin{array}{l}\text { - has high complementarity with a technique of } \\
\text { "Global Reporting Initiative" (GRI); } \\
\text { - contains the blocks of indicators differentiated } \\
\text { on the main spheres of action (economic. social, } \\
\text { ecological); } \\
\text { - it is focused on the Russian system in } \\
\text { accounting and statistical reporting; } \\
\text { contains detailed methodical explanations for } \\
\text { calculation of indicators in Russian conditions. }\end{array}$ & $\begin{array}{l}\text { - does not include a number of } \\
\text { important factors of sustainable } \\
\text { development on the basis of } \\
\text { interested parties' requirements: } \\
\text { energy saving, labor laws of the } \\
\text { person, innovative management, etc.; } \\
\text { - the assessment objectivity is in } \\
\text { many respects limited a set of } \\
\text { standard data for the Russian } \\
\text { organization; } \\
\text { - the aspect of administrative } \\
\text { innovations and standards of } \\
\text { corporate responsibility is } \\
\text { insufficiently disclosed. }\end{array}$ \\
\hline Rating Era Interfax & $\begin{array}{l}\text { - it is carried out in a section of different types of } \\
\text { economic activity for the purpose of carrying out } \\
\text { comparative analysis; } \\
\text { - discloses aspects of power, technological and } \\
\text { environmental efficiency of the organization; } \\
\text { - it is focused on the Russian system of } \\
\text { accounting and statistical reporting of the } \\
\text { organization. }\end{array}$ & $\begin{array}{l}\text { - it is carried out on a voluntary basis; } \\
\text { - rather narrow set of indicators for } \\
\text { monitoring and control; } \\
\text { - it is not focused mainly on the } \\
\text { concept of the company sustainable } \\
\text { development. }\end{array}$ \\
\hline
\end{tabular}

Source: Authors.

\section{Conclusion}

Thus, the main international and Russian methodological approaches to formation of a system of indicators considered in table 1 for assessment of sustainable development have both the methodological advantages, and the shortcomings. Together within a research perspective in terms of stakeholder approach methodological approaches to formation of integrated assessment of level of the organization sustainable development on the basis of formation of indexes and rating models are of considerable interest.

The rating systems of an economic entity development assessment within stakeholder approach are of scientific and practical interest in terms of assessment of investment attractiveness of the organization and its long-term social and economic stability. Therefore Russian companies require an organic combination of the principles and approaches put in the system of the corporate reporting "Bloomberg ESG Index" and also a technique Interfax Era Rating which applies aspects of the power, technological and environmental efficiency of the organization. At the same time it is necessary to 
add to the given techniques a system of indicators of "Global Reporting Initiative" (GRI) which are applied within a technique as the most widely used in the international corporate governance practice and also the technique of the Russian Union of Industrialists and Entrepreneurs (RUIE) focused on the Russian system in accounting and statistical reporting of the organization.

\section{References}

1. A.Yu. Yakovleva, O.A. Pisarenko, Open programme stakeholders' expectations - Is it possible to manage? Russian Journal of Project Management, 6(1), 15-24 (2017). [in Rus.].

2. M.H. Zaharia, F.A. Hodorogea, Research stakeholders identification using an mobile entity's framework. Expert Systems with Applications, 72, 18-29 (2017).

3. R.E. Freeman, Strategic management: A stakeholder approach (Pitman, Boston, 1984).

4. S. Antognelli, M. Vizzari, Landscape liveability spatial assessment integrating ecosystem and urban services with their perceived importance by stakeholders. Ecological Indicators, 72, 703-725 (2017).

5. V.A. Semidotsky, A.E. Akopyan, The stakeholder-focused methodical approach to strategic planning of development of industrial business. Journal of Economy and Entrepreneurship, 6(95), 1026-1031 (2018). [in Rus.].

6. V.A. Korovina, Assessment of efficiency of the enterprise activity with use of a system of the balanced indicators. Bulletin of South Ural State University, 20(120), 40-51 (2008). [in Rus.].

7. R.W. Ackerman, The social challenge to business (Harvard University Press, Cambridge, 1975).

8. R.A. Buchholz, Public policy issues for management (Prentice Hall, Upper Saddle River, New Jersey, 1991).

9. S.C. Zyglidopoulos, The issue life-cycle: Implications for reputation for social performance and organizational legitimacy. Corporate Reputation Review, 6(1), 70-81 (2003).

10. R. van Tulder, A. van der Zward, International business-society management: Linking corporate responsibility and globalization (Routledge, London, 2006).

11. S. Zadek, The Path to corporate responsibility. Harvard Business Review (2004). URL: https://hbr.org/2004/12/thepath-to-corporate-responsibility. Accessed: 27.09.2019.

12. Yu.A. Sedykh, Theoretical and methodical approaches to branch priorities assessment in business development: On the example of the small industrial enterprises of the Rostov region. Ph.D. thesis. Rostov-on-Don: Rostov State University of Economics (2004). [in Rus.].

13. E.V. Korobeynikova, System assessment of efficiency of consumer cooperation activity. Problems of Modern Economy, 4(32), 371-375 (2009). [in Rus.].

14. N.N. Kireev, Performance indicators of entrepreneurial activity in the region. Regional Economy and Management: Online Scientific Journal, 2(26) (2011). URL: https://eee-region.ru/article/2605/. Accessed: 26.09.2019. [in Rus.].

15. T.N. Zhukova, Marketing aspects of strategic management of the organization's relationships with stakeholders, Bulletin of Faculty of Management of Saint Petersburg State University of Economics, 1-1, 272-276 (2017). [in Rus.]. 